\title{
A REPORT OF THE OCCURRENCE OF A BLUE-GREEN ALGA, ANABAENA, IN CELLS OF A GREEN ALGA , RHIZOCLONIUM
}

M.V.S. RAJU and BERNARD DE VRIES, George F. Ledingham Herbarium, Biology Department, University of Regina, Regina, SK. S4S 0A2

Anabaena and Rhizoclonium are filamentous (thread-like) algae (Fig. $1 \mathrm{~A}, \mathrm{~B})$ which occur in great abundance in the lakes of southern Saskatchewan, often contributing to the formation of algal blooms. ${ }^{4}$ Anabaena, a self-sustaining, photosynthesizing and free-floating alga, is classified as a prokaryote (cells containing primitive or unorganized nuclei), blue-green alga or a cyanobacterium. Rhizoclonium, which is also a self-sustaining and photosynthesizing green alga, is classified as an eukaryote (cells with true organized nuclei). In the early stages of their development, the branched filaments of this alga remain attached to various substrata, such as rocks, plants, etc. The filaments, when mature, get detached from the substrata to become free-floating. These filaments fragment profusely, contributing to the algal abundance or bloom in lakes. ${ }^{4}$

Often, the large cells of Rhizoclonium filaments, when examined under a compound microscope, will contain many short filaments of $A n-$ abaena, indicating some sort of mutualistic (symbiotic) relationship of both kinds of algae (Fig. 1C). It is not clear, at present, how these filaments enter into the vegetative cells of the host alga, Rhizoclonium. It is, however, well known that cells of $A n$ abaena, within the host cells or out- side, can fix elemental nitrogen from the atmosphere and also secrete many nitrogenous products, which, no doubt, benefit the growth of the host alga and perhaps also other aquatic plants in the same ecosystem. ${ }^{5}$

The cells of the host filament, Rhizoclonium, collected late in the growing season (September-October) become modified into thick-walled cells, called akinetes (Fig. 1D, E). These akinetes, which are asexually reproducing structures, may over-winter until the following spring when they germinate to produce new filaments or trichomes. The occurrence of many akinetes (Fig. 1D, E) in the host filaments is quite common and significant, indicating that the alga does indeed reproduce predominantly by asexual means. ${ }^{6}$ This type of asexual reproduction in Rhizoclonium is known to be promoted by excessive production of nitrogenous substances produced by the endophytic (living within) Anabaena trichomes. ${ }^{1}$

The exact physiological relationship between Rhizoclonium and Anabaena is not clear. The filaments of the latter do, however, live within the vegetative cells of Rhizoclonium. The green cells of the former, on the other hand, facilitate the lodging of 


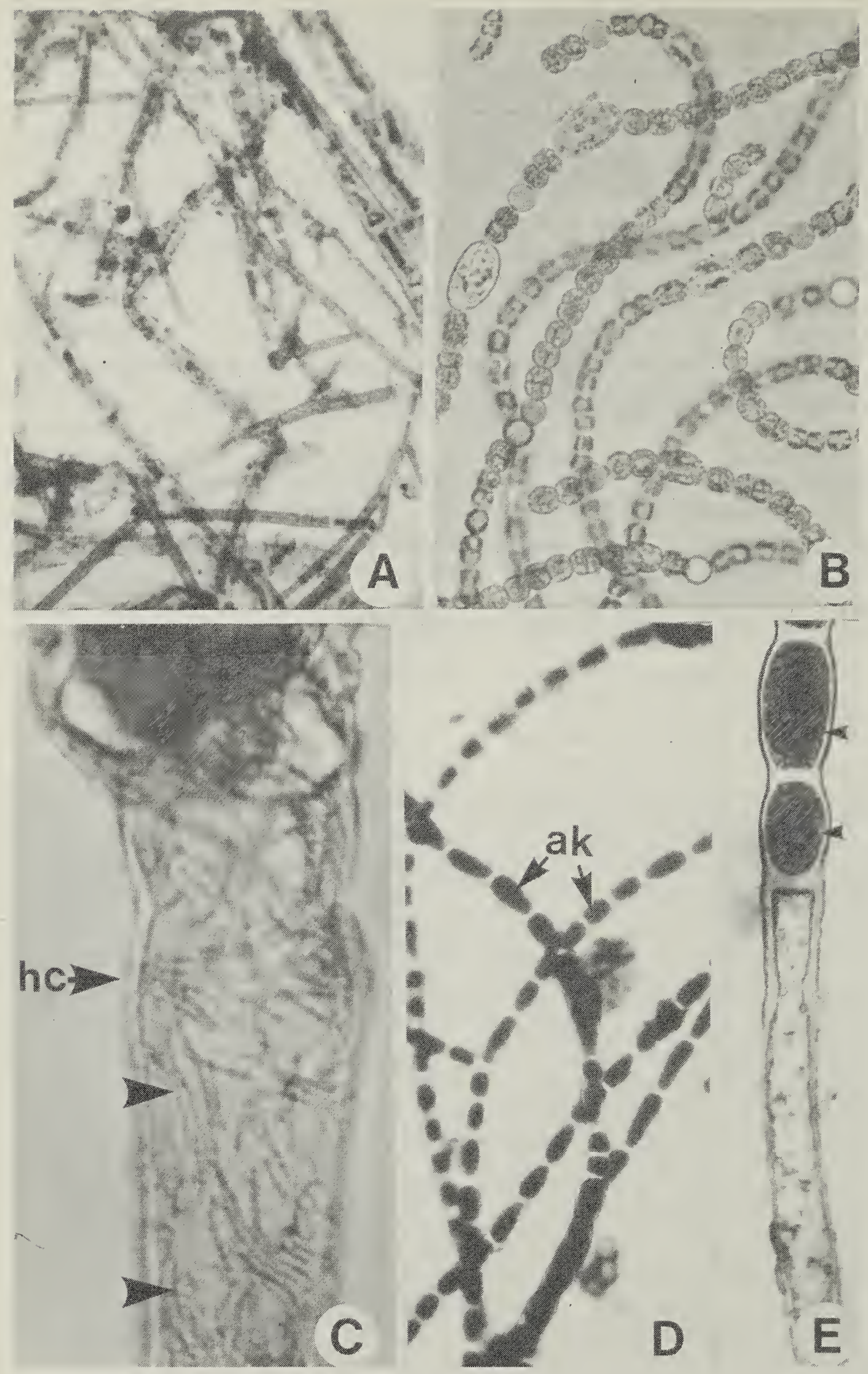

Figure 1. Rhizoclonium sp. and Anabaena $s p$. filaments collected from Wascana Lake. $A$, vegetative filaments of Rhizoclonium (green alga). $\times 40 . B$, filaments or trichomes of Anabaena (blue-green alga). $\times 340 . C$, Enlarged view of a vegetative cell (hc, host cell; arrow heads indicate endophytic trichomes of Anabaena) of Rhizoclonium containing many endophytic trichomes of Anabaena. $x 900 . D$, Filaments of Rhizoclonium collected late in July showing chains of akinetes (ak), asexually reproducing cells. $x$ 90. E, Enlarged filament of Rhizoclonium with akinetes (small arrow heads). $\times 315$. 
the Anabaena filaments, which, in turn, provide different nitrogenous compounds that are necessary for the growth in abundance of the host filaments. This is somewhat similar to the occurrence of a blue-green alga, Richelia, thriving in Rhizosolenia, a single-celled aquatic diatom (an alga), and ecologically a successful genus. ${ }^{6}$ There are many instances where the blue-green algae live in other plants and help in atmospheric nitrogen assimilation. ${ }^{1,2,3}$ The present note reports the endophytic nature of a blue-green alga, Anabaena in the vegetative cells of a green alga, Rhizoclonium, both of which independently form important components of algal blooms in lakes of southern Saskatchewan.

\section{References}

1. BOLD, H.C. and M.J. WYNNE. 1978. Introduction to the algae: structure and reproduction. Prentice-Hall, Inc. Englewood Cliffs, New Jersey.

2. DESIKACHARI, T.V. 1959. Cyanophyta. Indian Council of Agricultural Research, New Delhi.

3. LEE, R.E. 1989. Phycology. 2nd edition. Cambridge University Press, New York.

4. RAJU, M.V.S., J.E. HINES and L.A. PENDLEBURY. 1972. Algal blooms. Blue Jay 30:56-61.

5. STEWART, W.D.P. 1973. Nitrogen fixation. pp. 260-278. In: CARR, N.G. and WHITTON, B.A. editors. The Biology of the blue-green algae. The University California Press, Berkeley, California.

6. WEST, G.S. and F.E. FRITSCH. 1927. A treatise on the British freshwater algae. Cambridge University Press, London, UK.

\section{WANTED}

Rare Reptile and Amphibian Observations for the status report for COSEWIC (Committee on the Status of Endangered Wildlife in Canada). If you have any observations of Western Hognose Snake, Plains Spadefoot Toad, Great Plains Toad or Prairie Rattlesnake send them, as soon as possible, to COSEWIC Status Reports, Saskatchewan Herpetology Atlas Project, Box 1574, Saskatoon, SK. S7K 3R3. ANY observation (even if only approximate for date, number, etc.) is important. Andrew Didiuk (home: 306-3732213/ office: 306-975-4005/fax: 306-875-4089). 


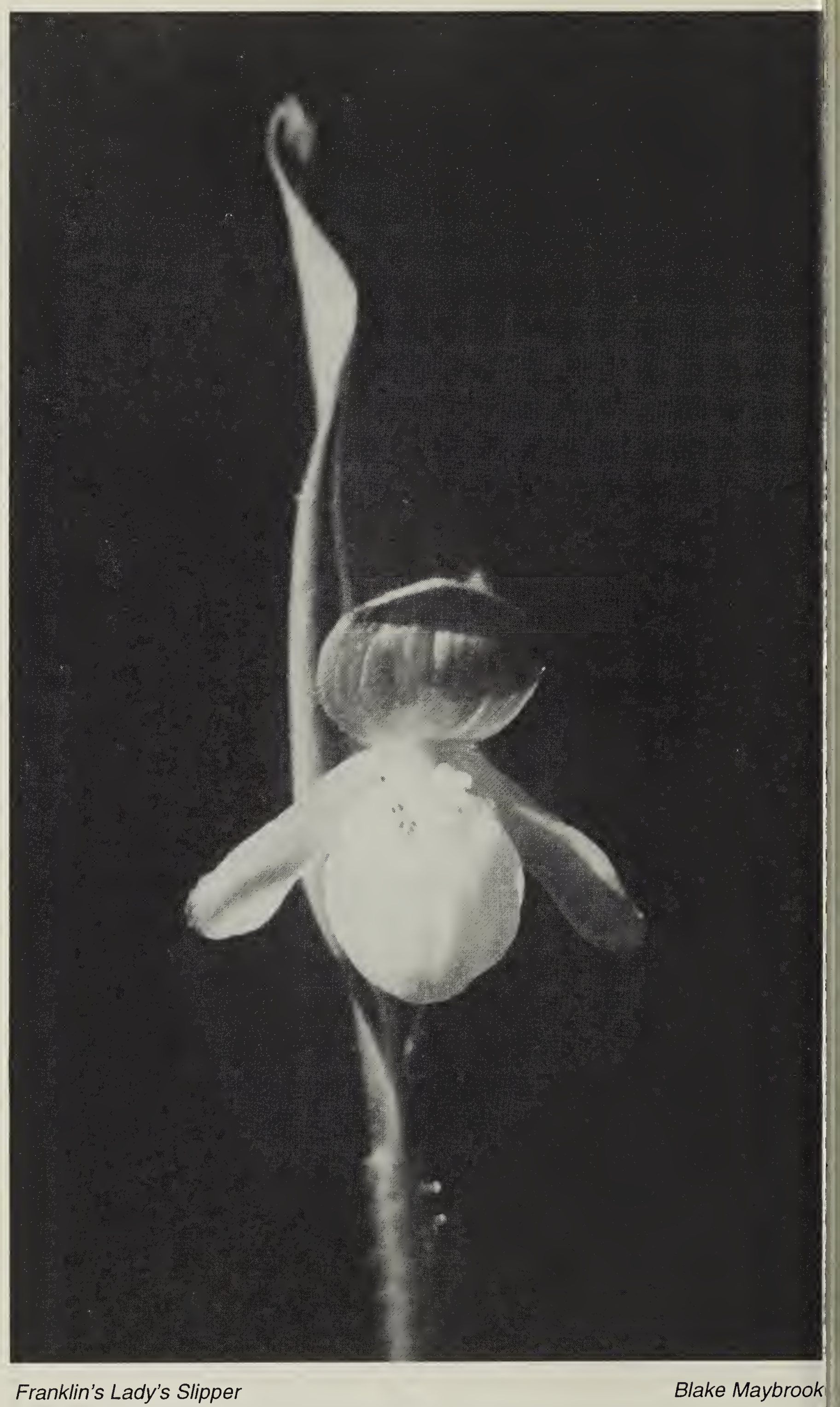

